\title{
New Antarctic records of Herpyllobius Steenstrup and Lütken, 1861 (parasitic Copepoda) from the EASIZ-III cruise, with description of two new species*
}

\author{
PABLO J. LÓPEZ-GONZÁLEZ ${ }^{1}$ and JOSÉ BRESCIANI ${ }^{2}$ \\ ${ }^{1}$ Departamento de Fisiología y Zoología, Facultad de Biología, Universidad de Sevilla, Reina Mercedes, 6, \\ 41012-Sevilla, Spain. E-mail: pjlopez@us.es \\ ${ }^{2}$ Department of Zoology, Royal Veterinary and Agricultural University, Thorvaldsensvej 40, DK-1871 Frederiksberg C, \\ Denmark. E-mail: job@kvl.dk
}

\begin{abstract}
SUMMARY: Two new species of the genus Herpyllobius Steenstrup and Lütken, 1861, H. vanhoeffeni, and H. luetzeni are described associated with polynoid polychaetes collected during the EASIZ III cruise in the Bransfield Strait, Antarctic Peninsula. New records of Herpyllobius antarcticus Vanhöffen, 1913, and H. polarsterni López-González et al., 2000 from Antarctic Peninsula and Eastern Weddell Sea are also given. Including the present records, 17 species of Herpyllobius are now known, 11 of which having been reported from the Southern Hemisphere. The ordinal position of the Herpyllobiidae is discussed according to phylogenetic inferences from the antennular ontogenetic features of the copepodid males of two of the three known genera in the family, Herpyllobius and Eurysilenium Sars, 1870.
\end{abstract}

Key words: parasitic Copepoda, Herpyllobiidae, Herpyllobius, Antarctica.

\section{INTRODUCTION}

The family Herpyllobiidae Hansen, 1892 is one of the most highly transformed families among the parasitic Copepoda. This family represents a group of genera of uncertain ordinal placement (Herpyllobius Steenstrup and Lütken, 1861, Eurysilenium Sars, 1870, and the ill-defined Phallusiella Leigh-Sharpe, 1926), all parasitise polynoid polychaetes (Lützen, 1964). Herpyllobius is the most speciose genus of the family with 15 species, whereas Eurysilenium and Phallusiella have two species each. The female body of Herpyllobius comprises two portions connected by a short stalk: an endosoma inside the host body with

\footnotetext{
*Received January 10, 2001. Accepted June 13, 2001.
}

attachment and nourishment functions; and a nearly globular external ectosoma, carrying the genital apertures with the egg masses (Lützen, 1964, 1966). Males are also highly transformed, comprising a flask-shaped body containing a cement gland and two spermatophores with their respective spermiducts (Jensen, 1900). Adult males usually remain inside the exuvia of the last copepodid stage. They are often found in abundance close to the genital apertures of the females (see López-González et al., 2000: figs. 4C and 5A), probably attracted by the secretion of a series of pores located above the genital area (see Jensen, 1900).

Among the 15 species of Herpyllobius described thus far, nine have been reported from the southern hemisphere. In this paper we present new records of 
two previously identified species (H. antarcticus Vanhöffen, 1913, and H. polarsterni LópezGonzález et al., 2000), and the description of two new species from the Bransfield Strait, in the Antarctic Peninsula. All these species were collected during the EASIZ III cruise (17 March-11 May 2000). Including the discovery of these two new species, 17 species of the genus are known now, 11 of which are restricted to the Southern Hemisphere.

\section{MATERIAL AND METHODS}

Polychaetes infected with parasitic copepods were collected in Antarctic waters (Fig. 1) during the EASIZ III (Ecology of the Antarctic Sea Ice Zone) cruise ANT XVIII/3 on board the R/V Polarstern during the austral autumn of 2000 . The material was collected with the aid of bottom trawl or Agassiz trawl, sorted, labelled and fixed on board. The majority of the material collected was fixed in $5 \%$ formalin in sea water. However, in addition, some material was also fixed on board using two different fixatives to further anatomical and molecular studies: $2.5 \%$ glutaraldehyde in 0.2 $\mathrm{M}$ cacodylate buffer at $\mathrm{pH} 7.3$, and $96 \%$ ethanol respectively.

Selected material was postfixed in $1 \% \mathrm{OsO}_{4}$ in $0.2 \mathrm{M}$ cacodylate buffer at $\mathrm{pH} 7.3$ and subsequently critical point dried, mounted on stubs, coated with gold-palladium and observed with a JEOLJSM 840.

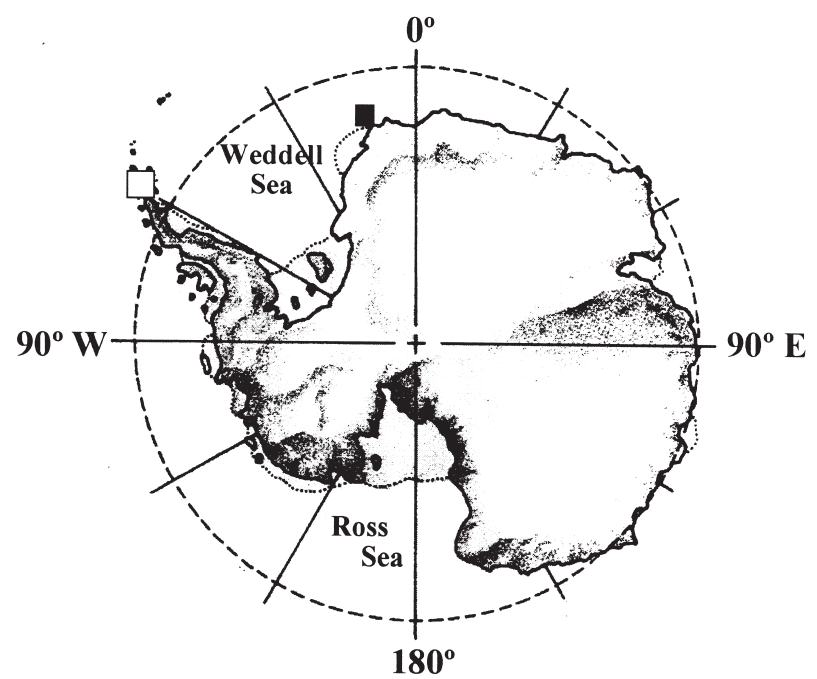

FIG. 1. - Procedence of the Herpyllobius material studied. o: EASIZ III cruise, stns. 56/166 and 56/168 (Herpyllobius vanhoeffeni sp. nov., Herpyllobius polarsterni, Herpyllobius luetzeni sp. nov., and Herpyllobius antarcticus). n: EPOS III cruise, stn. $291 \mathrm{nr}$. 14 (Herpyllobius polarsterni).
The copepods fixed in formalin were removed from the polychaetes under a stereomicroscope and transferred to $70 \%$ ethanol. For light microscopical investigations, some specimens were stained with Chlorazole black E, partially dissected, mounted in lactophenol and sealed with Entellan. All figures were drawn with the aid of a camera lucida.

The species studied have been deposited in the Zoologisches Institut und Zoologisches Museum, Hamburg (ZMH), and the Zoology Section (SZ) of the Faculty of Biology, University of Seville.

\section{RESULTS}

Family HeRPYLLOBIIDAE Hansen, 1892

Genus Herpyllobius Steenstrup and Lütken, 1861

Herpyllobius vanhoeffeni sp. nov. (Figs. 2A-C; 3)

Material examined. Seven females, two of them ovigerous, and two in an early stage of development, parasitising the polynoid polychaete Eulagisca corrientis McIntosh, 1885. EASIZ III cruise ANT

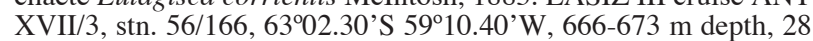
April 2000, Bransfield Strait, Antarctic Peninsula. The holotype has been deposited in the $\mathrm{ZMH}(\mathrm{K}-39883)$. The rest of the material is deposited in the SZ (COP-104).

Description of the females (Figs. 2A, B; 3A-F, I). Adult female with ectosoma up to $3,3 \mathrm{~mm}$ in length and $2.4 \mathrm{~mm}$ maximum width, pear-shaped, the underside slightly concave, more accentuated by protruding genital swellings. Genital swellings prominent and heavily sclerotised, with distinct medio-terminal swelling between them. Four minute sclerotised dots forming semicircle above genital swellings. Each sclerotised dot with terminal pore. Males present in area between sclerotised dots and genital swellings. Ovisacs drop-shaped, short and thick, terminally rounded, up to $2.3 \mathrm{~mm}$ in length and $1.4 \mathrm{~mm}$ in width. Stalk distinct, emerging from underside of ectosoma, clearly displaced to genital area. Sclerotised ring present; cleared in lactic acid showing border shortly curved toward ectosoma (Figs. 3I, J). Endosoma flat and oblong, usually tongue-shaped with waving edges, rounded ends and few ramifications (Figs. 2A; 3I).

Young female (Figs. 3B, C) with typical grapeshaped ectosoma, $1.3 \mathrm{~mm}$ in length. Genital apertures not functional. Stalk clearly displaced to anterior zone. Endosome as previously described for adult female. 

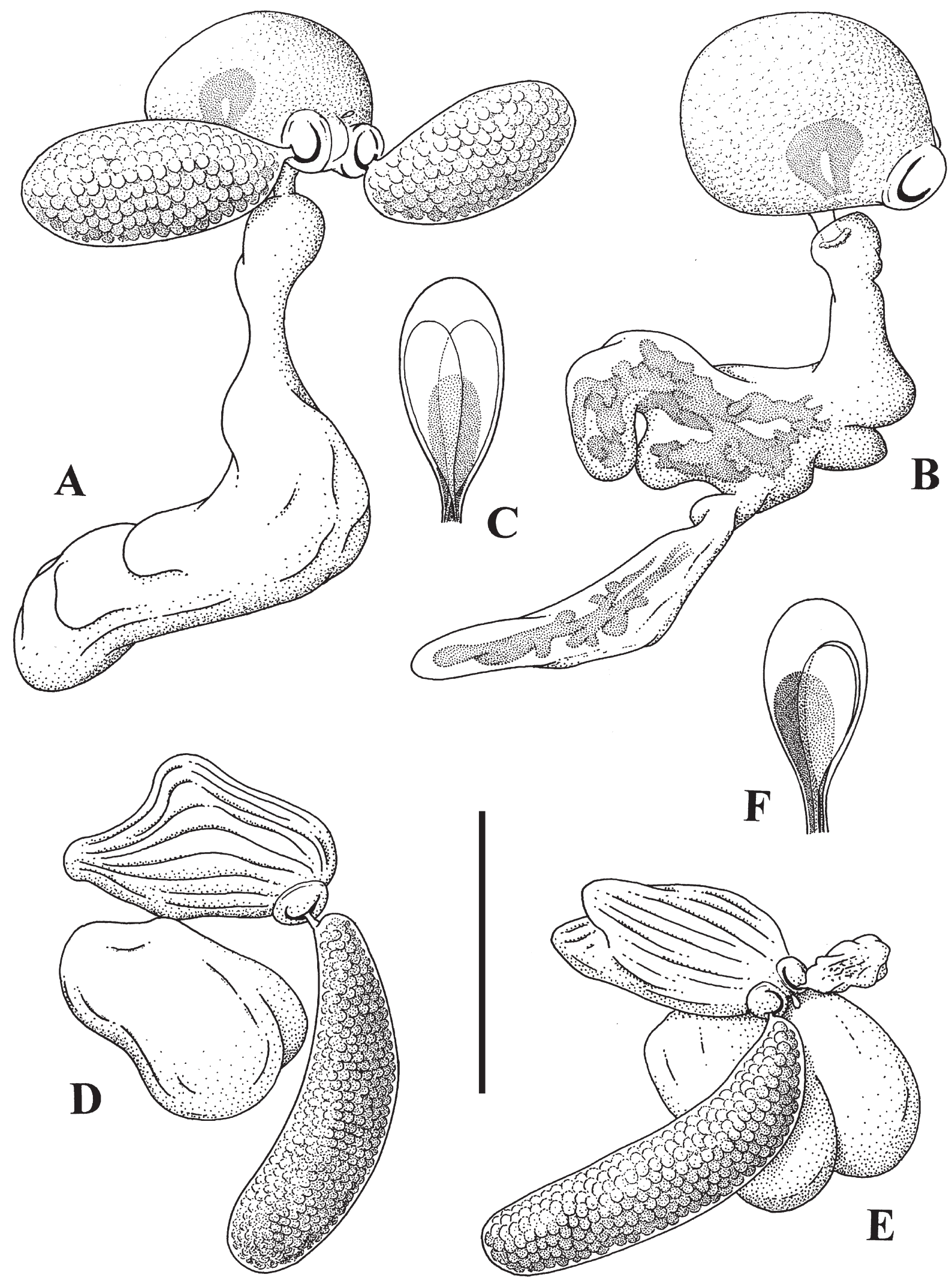

FIG. 2. - A-C Herpyllobius vanhoeffeni sp. nov. A Adult ovigerous female, postero-lateral. B Adult female, lateral; C Adult male showing both spermatophores (remains of the copepodid exuvium not illustrated); D - F Herpyllobius luetzeni sp. nov. D Adult ovigerous female (holotype), lateral; E Adult ovigerous female (holotype), postero-oblique; F Adult male showing both spermatophores (remains of the copepodid exuvium not illustrated). Scale bars: A, B, D and $\mathbf{E} 2 \mathrm{~mm} ; \mathbf{C}$ and $\mathbf{F} 150 \mu \mathrm{m}$. Drawn by Beth Beyerholm. 

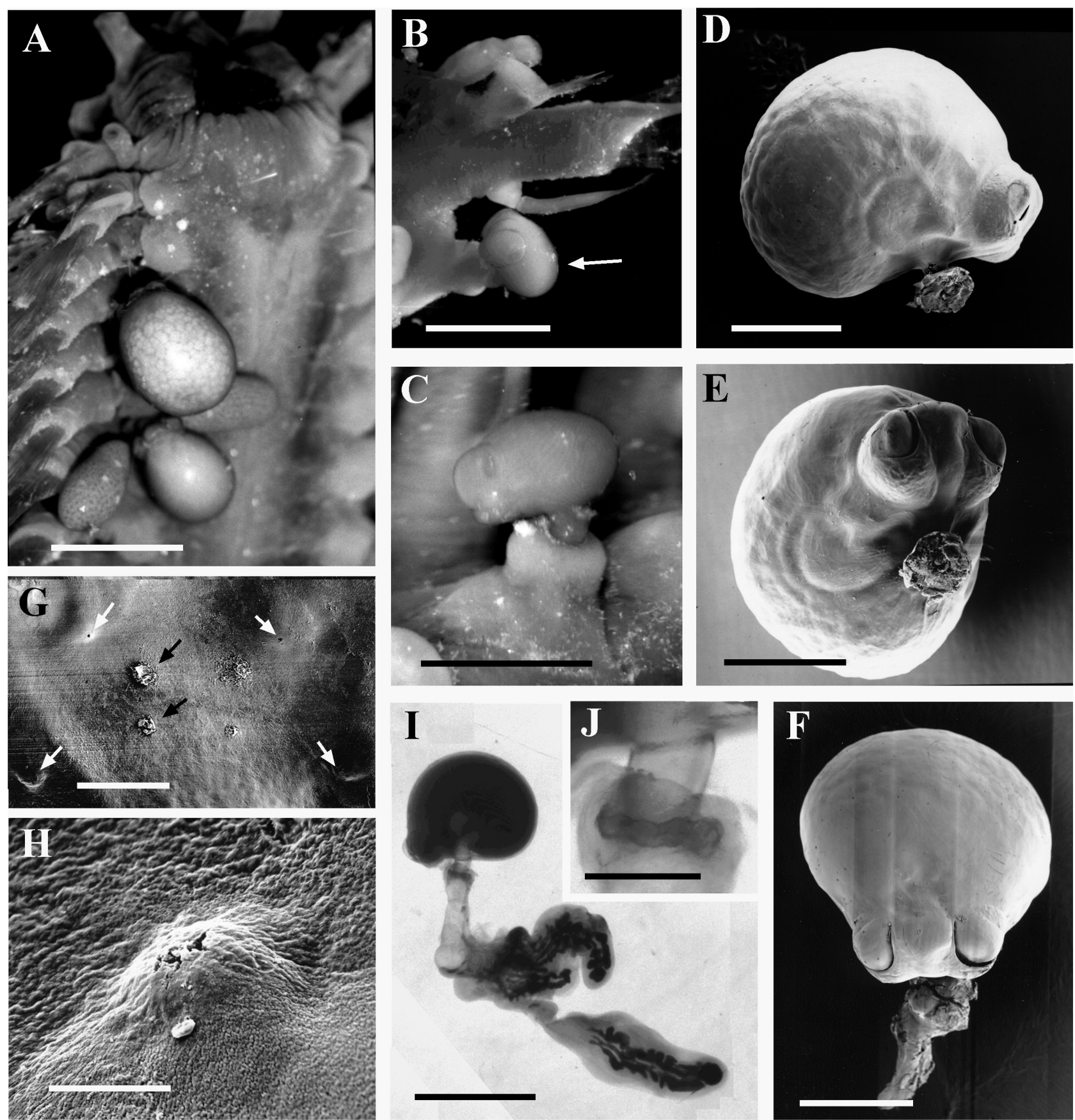

FIG. 3. - A-J Herpyllobius vanhoeffeni sp. nov. A Ventral view of Eulagisca corrientis McIntosh, 1885 showing two adult females, one of them ovigerous. B Young female (arrowed) in its natural position with respect to the host parapodia. C Detail of the same specimen (note that the genital apertures are still not functional, and also the anterior displacement of the stalk). D Adult female ectosoma, lateral. E Adult female ectosoma, underside (note the prominent medio-terminal swelling). F Adult female ectosoma, posterior. G Adult female, area above the genital swellings showing the four sclerotised dots (white arrows) with their respective pores, and old placement of male copepodids (black arrows). H Detail of one of the sclerotised dots of G. I Adult female in lactic acid (note the internal system of diverticula in the endosoma). J Detail of the sclerotised ring of same specimen. Scale bars: A 3mm; B $2 \mathrm{~mm} ; \mathbf{C} 1.5 \mathrm{~mm} ; \mathbf{D}$, E and F $1 \mathrm{~mm} ; \mathbf{G ~} 100 \mu \mathrm{m} ; \mathbf{F} 20 \mu \mathrm{m}$; I

$3 \mathrm{~mm} ; \mathbf{J} 450 \mu \mathrm{m}$.

Description of the males (Fig. 2C). Body flaskshaped, $200 \mu \mathrm{m}$ in length and $80 \mu \mathrm{m}$ in width, without appendages. Two spermatophores visible through cuticle. Males attached to region above females' genital swellings.
Position on host (Figs. 3A, B). In the single polynoid studied, all the copepods were found attached to the ventral part of the parapodia, with the anterior part of the ectosoma toward the mid-ventral axis of the polychaete. 
Etymology. The species is named after the carcinologist E. Vanhöffen.

Discussion. According to the artificial group of Herpyllobius species first proposed by Lützen and Jones (1976) and later updated by López-González et al. (2000), Herpyllobius vanhoeffeni should be placed within the first group characterised by the possession of sclerotised dots in the area above the genital swellings. Five species are included in this group [H. arcticus Steenstrup and Lütken, 1861, $H$. polynoes (Krøyer, 1863), H. elongata Lützen, 1967, $H$. hartmanae Lützen and Jones, 1976, and H. rotundus Lützen and Jones, 1976], distinguishable by the number of sclerotized dots and the presence or absence of a slightly prominent hump encircled by these sclerotized dots.

Herpyllobius polynoes and $H$. rotundus possess a prominent hump encircled by sclerotised dots, which is absent in $H$. vanhoeffeni.

Herpyllobius arcticus and $H$. elongata have four sclerotised dots, as in $H$. vanhoeffeni. However, $H$. arcticus and $H$. vanhoeffeni clearly differ regarding the general aspect of the ectosoma (almost spherical in H. arcticus, with the genital areas much more protruding in $H$. vanhoeffeni), the endosoma (lump-shaped with many small and large irregularly shaped diverticulae in $H$. arcticus, and tongue-shaped with few ramifications in H. vanhoeffeni), the host range, and their geographical distribution (see Lützen, 1964 for more details).

Herpyllobius elongata is remarkably different from $H$. vanhoeffeni in the shape of the ectosoma, ovisacs, and endosoma. In addition, the relative position of the four sclerotised dots, the polynoid host, and the geographical range also differ (see Lützen, 1967 for more details).

Herpyllobius hartmanae seems to be the closest species to $H$. vanhoeffeni in the shape of the endosoma, position on the host (on the ventral side of the parapodia) and geographical area (Ross Sea for $H$. hartmanae and Bransfield Strait for $H$. vanhoeffeni). However, $H$. vanhoeffeni differs from $H$. hartmanae in the shape of the ectosoma; the posterior area, where the genital swellings are located, is rounded in $H$. hartmanae, but prominent in $H$. vanhoeffeni. Thus, the appearance of the genital swellings is inconspicuous in the former species and remarkably distinct in the new species. Furthermore, the anterior area (opposite the genital swellings) is distinctly prominent in $H$. hartmanae but rounded in $H$. vanhoeffeni. A richly lobulate area, where the sclerotised ring is included, is distinct in $H$. hartmanae and absent in $H$. vanhoeffeni. The shape and dimensions of the ovisacs have been used, taking into account the reasonable variability, as distinctive characteristics between species of Herpyllobius. In $H$. hartmanae the ovisacs are elongated, straight or very slightly curved, $9 \mathrm{~mm}$ long and $1.8 \mathrm{~mm}$ wide; while in $H$. vanhoeffeni these are drop-shaped, $2.3 \mathrm{~mm}$ long and $1.4 \mathrm{~mm}$ wide. The polynoid host is also different (Laetmonice producta Grube for $H$. hartmanae, but Eulagisca corrientis for $H$. vanhoeffeni). However, since no new data about the host range of these two species have been recorded, we prefer not to use this character to distinguish between the two copepod species.

If the "sclerotised dots", and their associated glands, are involved in the attraction of male copepodids, they should be present in all Herpyllobius species. It is possible, therefore, that the relative development of these structures could be a subjective taxonomic character depending on the equipment and methodology used in making the observations, and should be checked by SEM in all recognised species of the genus.

The presence of a medio-terminal swelling between the genital swellings was the characteristic used to define the second group of species in Herpyllobius. Eight species can be grouped together on the basis of this characteristic: $H$. antarcticus Vanhöffen, 1913, H. cordiformis Lützen, 1964, $H$. australis Lützen, 1964, $H$. gravieri Lützen, 1964, H. nipponicus Lützen, 1964, H. antepositus Stock, 1986, H. lobosaccus Stock, 1986, and H. stocki López-González et al., 2000 (see Lützen, 1964 and López-González et al., 2000 for additional references). Herpyllobius vanhoeffeni is clearly distinguishable from all these species by the shape of the ectosoma, endosoma, and ovisacs. Herpyllobius gravieri (after Lützen 1964: fig. 19) seems to be the closest species to $H$. vanhoeffeni by the relative position of the genital swellings and the medio-terminal swelling, and by the host (the endosoma is unknown for $H$. gravieri). Illustrations of the ectosoma given by Gravier (1913) and reproduced by Lützen (1964: figs. 20, 21) clearly belong to a different species. Discrepancies in shape of the ectosoma of $H$. gravieri (see Lützen, 1964: figs. 1921) cannot be attributed to the reproductive stage of the specimen. 

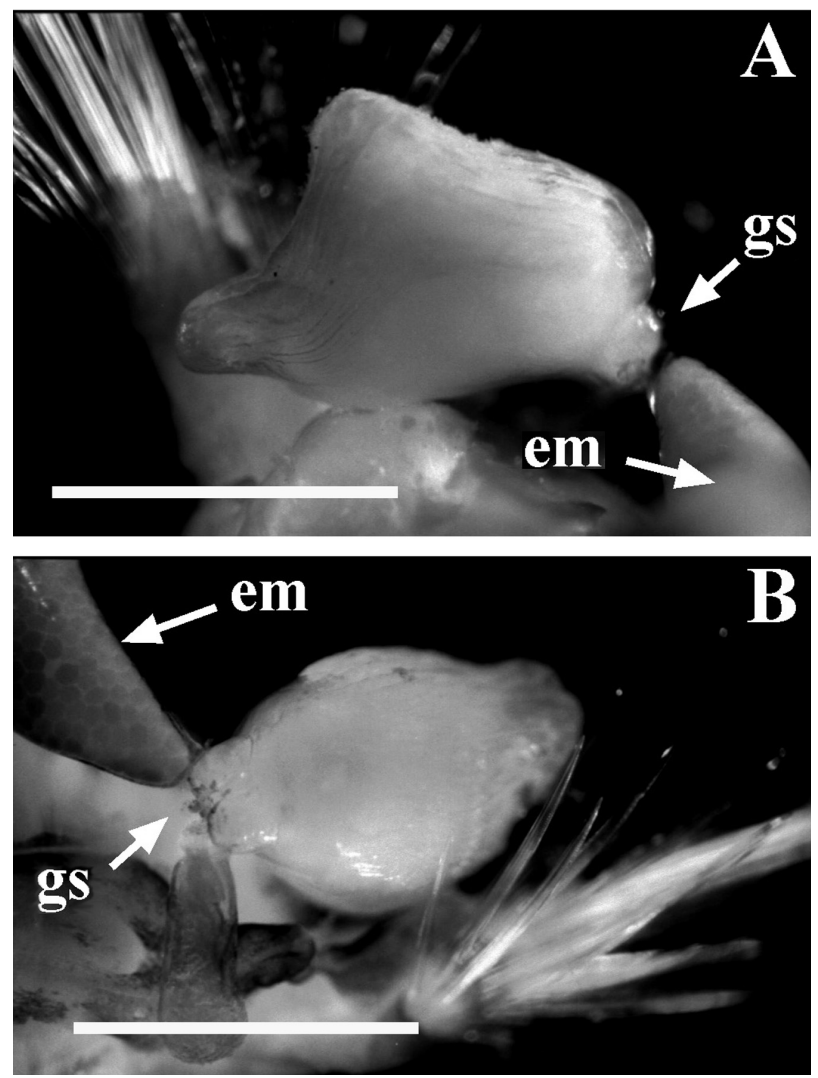

FIG. 4. - A-B Herpyllobius luetzeni sp. nov. ZMH (K-39884) Holotype. A Ovigerous female ectosoma, lateral; B Ovigerous female ectosoma, dorso-lateral. Scale bars: A and B $750 \mu \mathrm{m}$. Abbreviations: em, egg mass; gs, genital swellings.

Herpyllobius luetzeni sp. nov. (Figs. 2D-F, 4)

Material examined. One ovigerous female (holotype) associated with the polynoid polychaete Harmothoe cf. spinosa Kinberg, 1855. EASIZ III cruise ANT XVII/3, stn. 56/158, 6304.70’S 57 31.60'W, 94-95 m depth, 26 April 2000, Bransfield Strait, Antarctic Peninsula. The holotype has been deposited in the $\mathrm{ZMH}$ (K-39884). The host polynoid has been deposited in the ZMH (P24389).

Description of the female (Figs. 2D, E; 4). Adult female with ectosoma up to $2.8 \mathrm{~mm}$ in length and $1.4 \mathrm{~mm}$ maximum width, triangular, with two divergent anterior humps, the proximal one being more developed. Underside slightly convex. Lateral sides with deep longitudinal ridges. Genital swellings prominent and heavily sclerotised, closely placed to each other, without any free space or medio-terminal swelling between them. No sclerotised dots above genital swellings. Males present, attached at limit of genital swellings. Ovisacs elongate, wider distally, terminally rounded, up to $4.3 \mathrm{~mm}$ in length and 1 $\mathrm{mm}$ in width. Stalk short, emerging from underside of ectosoma, clearly displaced to anterior area. Characteristics of sclerotised ring not observed due to scarcity of available material. Endosoma massive, widely bilobate.

Description of the males (Fig. 2F). Body flaskshaped, $194 \mu \mathrm{m}$ in length and $83 \mu \mathrm{m}$ in width, without appendages. Two spermatophores visible through cuticle. Males attached to region above genital swellings.

Position on host. The single female copepod studied was found attached to the dorso-lateral side of the body wall of the polynoid, between parapodia, with the plane of symmetry perpendicular to the sagittal plane of the polychaete.

Etymology. The species is named after our colleague Jørgen Lützen, one of the most important authors contributing to knowledge of the Herpyllobiidae.

Discussion. Among the species included in the genus Herpyllobius, H. luetzeni is only comparable to $H$. haddoni Luitzen (1964) by the possession of two anterior humps, and lateral ridges on both sides of the ectosoma. However, in the former species the proximal hump is much more developed, the genital swellings have no free space between them (compare Lützen, 1964: fig. 9 and Figs. 2E, 4B of the present paper), the ovisacs are wider distally and not proximally (as occurs in $H$. haddoni), and the endosoma is massive and clearly bilobate (compare Lützen, 1964: figs. 8, 9 and Figs. 2D-E of the present paper). Additionally, $H$. haddoni has been reported from Puget Sound (North Eastern Pacific) associated with Harmothoe imbricata Linné, while $H$. luetzeni was collected from the Bransfield Strait (Antarctic Peninsula) associated with Harmothoe spinosa.

\section{Herpyllobius antarcticus Vanhöffen, 1913}

(Fig. 5)

Herpyllobius arcticus Gravier, 1912, 1913

Material examined. Two ovigerous females, attached to the prostomium of a specimen of the polynoid polychaete Polyeunoa laevis McIntosh, 1885. EASIZ III cruise ANT XVII/3, stn. 56/166, $63^{\circ} 02.30^{\prime} \mathrm{S} 59^{\circ} 10.40^{\prime} \mathrm{W}, 666-673 \mathrm{~m}$ depth, 28 April 2000, Bransfield Strait, Antarctic Peninsula. This material has been deposited in the SZ (COP-101).

Remarks. This species has been reported associated with the polynoid species Polyeunoa laevis 
(Vanhöffen, 1913: as Eniplo rhombigera) and Harmothoe gourdoni Gravier, 1911 (Gravier, 1912, 1913). In a recent account by López-González et al. (2000) this species was reported from the Eastern Weddell Sea, although the authors were unable to identify the polynoid host precisely. The present record confirms the specificity of this copepod species association with $P$. laevis.

\section{Herpyllobius polarsterni López-González, Bres- ciani and Conradi, 2000}

Material examined. One non-ovigerous female, attached to the dorsal part of the neuropodium of a specimen of the polynoid polychaete Eulagisca gigantea Monro, 1939. EASIZ III cruise ANT XVII/3, stn. 56/166, 63º2.30'S 59 $10.40^{\prime} \mathrm{W}, 666-673 \mathrm{~m}$ depth, 28 April 2000, Bransfield Strait, Antarctic Peninsula. This material has been deposited in the SZ (COP-102).

Additional material. 32 ovigerous females, attached to the dorsal part of the neuropodia of a specimen of the polynoid polychaete Eulagisca gigantean. EPOS III cruise, stn. $291 \mathrm{nr} .14,71^{\circ} 06.1^{\prime} \mathrm{S}$ $12^{\circ} 33.5^{\prime} \mathrm{W}, 499-515 \mathrm{~m}$ depth, 19 February 1989, Weddell Sea, Antarctica. This material has been deposited in the SZ (COP-103).

Remarks. This species was recently described by López-González et al. (2000) from the Eastern Weddell Sea during the EASIZ II cruise. The new discovery of this species in the same locality (present EPOS material) not only confirms the presence of this species in the Eastern Weddell Sea but suggests it is a common parasite of its polynoid host, with relatively high densities of infection. The present EASIZ material extends the distribution of this species to the Antarctic Peninsula on the same host, but with a lower intensity (only single female was found).

\section{REMARKS ON THE SPECIES OF HERPYLLO- BIUS FROM THE SOUTHERN HEMISHERE}

As above commented, 17 species are currently recognised in the genus Herpyllobius, 11 of them being reported from the Southern Hemisphere (see Lützen, 1964, Lützen and Jones, 1976, Stock, 1986, López-González et al., 2000, present paper) (Table I). As in all the herpyllobiids, the 11 species are mesoparasitic on polynoid polychaetes, mainly associated with species of the genus Harmothoe Kinberg, 1855. With respect to the location on the host's body, most of the species are located close to or on the parapodia; one species is invariably located attached to the prostomium ( $H$. antarcticus), and another on the ventral side of the parapodium (H. vanhoeffeni).

Concerning the geographical distribution of these 11 species, Antarctica is the richest area, and only

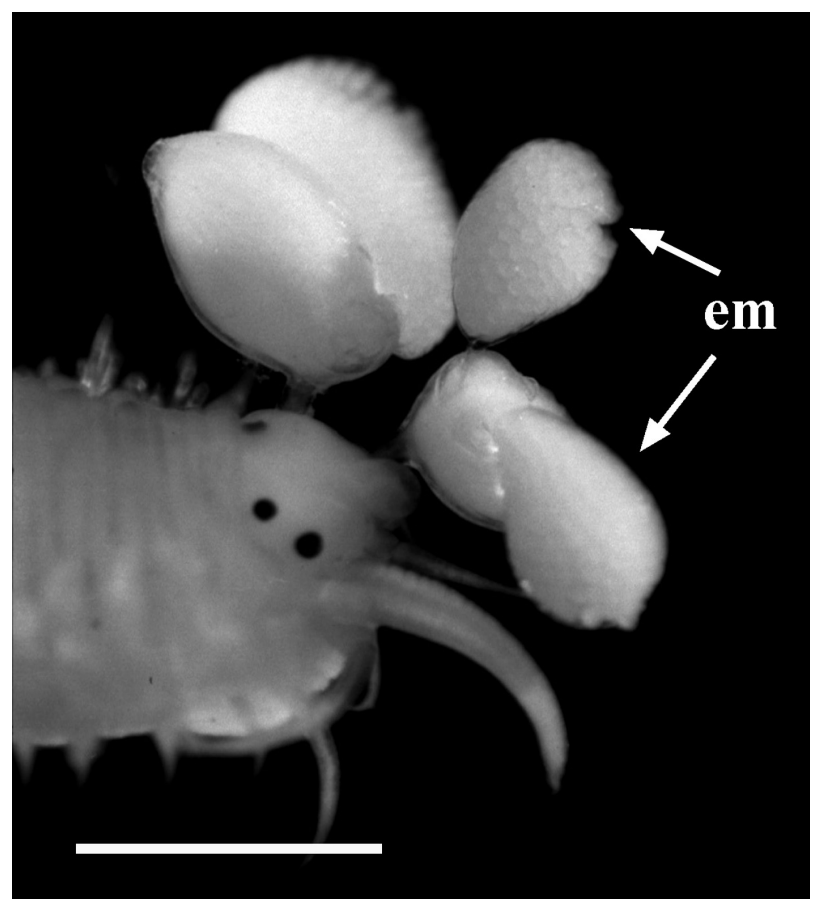

FIG. 5. - Herpyllobius antarcticus Vanhöffen, 1913. SZ (COP-101) two ovigerous females attached to the prostomium of the polynoid Polyeunoa laevis McIntosh, 1885. Scale bar: $2 \mathrm{~mm}$. Abbreviation: em, egg mass.

three species were found outside this area $(H$. rotundus from Cook strait, New Zealand; and H. antepositus and H. lobosaccus from Crozet Islands). Though few papers have been published on herpyllobiids from the Southern Oceans, it seems worth mentioning that four new species have been described from the same area after EASIZ cruises carried out during the austral summer of 1998 and autumn of 2000, including two new findings of $H$. antarcticus (see LópezGonzález et al., 2000 and present account).

Probably herpyllobiids are more frequent than previously reported. These parasitic copepods have been mainly reported from high latitudes in both hemispheres, the references in temperate (Laubier, 1961) or tropical waters (H. nipponicus Lützen, 1964) being scarce. A cooperative effort between polychaetologists and copepodologists will surely give much more information about the diversity, biology and specificity of these highly transformed crustaceans than that presently available.

\section{REMARKS ON THE ORDINAL POSITION OF HERPYLLOBIIDAE}

The family Herpyllobiidae has for a long time been given an uncertain ordinal position, appearing 
TABLE 1. - Species of the genus Herpyllobius reported from the Southern Hemisphere.

\begin{tabular}{|c|c|c|c|}
\hline Copepods & Host & Position on host & $\begin{array}{c}\text { Geographic and bathymetric } \\
\text { distribution }\end{array}$ \\
\hline H. antarcticus Vanhöffen, 1913 & $\begin{array}{l}\text { Polyeunoa laevis McIntoch } 1885 \\
\text { Harmothoe gourdoni Gravier, } 1911\end{array}$ & on the prostomium & $\begin{array}{l}\text { Antarctica } \\
350-673 \mathrm{~m}\end{array}$ \\
\hline H. australis Lützen, 1964 & Harmothoe spinosa Kinberg, 1855 & $\begin{array}{l}\text { dorso-laterally, on the body } \\
\text { wall between parapodia }\end{array}$ & $\begin{array}{l}\text { Cape Adare, Antarctica } \\
\text { no depth recorded }\end{array}$ \\
\hline H. gravieri Lützen, 1964 & Harmothoe spinosa Kinberg, 1855 & on the elytrophore & $\begin{array}{l}\text { Matha Bay, Antarctica } \\
380 \mathrm{~m}\end{array}$ \\
\hline H. hartmanae Lützen and Jones, 1976 & Laetmonice producta Grube, $1877^{(*)}$ & on the neuropodium & $\begin{array}{l}\text { Ross Sea, Antarctica } \\
\text { 476-496 m }\end{array}$ \\
\hline H. roundus Lützen and Jones, 1976 & Harmothoe sp. & directly on the body wall & $\begin{array}{l}\text { Turakirac Trench, } \\
\text { Cook Strait, } 640-658 \mathrm{~m}\end{array}$ \\
\hline H. antepositus Stock, 1986 & Lagissa irritans Marenzeller, 1904 & no data & $\begin{array}{l}\text { Crozet Islands } \\
365-485 \mathrm{~m}\end{array}$ \\
\hline H. lobosaccus Stock, 1986 & Lagissa irritans Marenzeller, 1904 & no data & $\begin{array}{l}\text { Crozet Islands } \\
485 \mathrm{~m}\end{array}$ \\
\hline H, polarsterni López-González et al., 2000 & Eulagisca gigantea Monro, 1939 & on the neuropodium & $\begin{array}{l}\text { Weddell Sea and Antarctic } \\
\text { Peninsula, 391-395 m }\end{array}$ \\
\hline H. stocki López-González et al., 2000 & \multicolumn{2}{|c|}{ Austrolaenilla antarctica Berström, 1916 on the neuropodium } & $\begin{array}{c}\text { Weddell Sea, } \\
\text { Antarctica, 395-417 m }\end{array}$ \\
\hline H. vanhoeffeni sp. nov. & Eulagisca corrientis McIntosh, 1885 & $\begin{array}{l}\text { on the ventral side } \\
\text { of the parapodium }\end{array}$ & $\begin{array}{l}\text { Antarctic Peninsula } \\
\quad 666-673 \mathrm{~m}\end{array}$ \\
\hline H. luetzeni sp. nov. & Harmothoe cf. spinosa Kinberg, 1855 & $\begin{array}{l}\text { on the dorso-lateral } \\
\text { side of the body wall }\end{array}$ & $\begin{array}{l}\text { Antarctic Peninsula } \\
\text { 93-94 m }\end{array}$ \\
\hline
\end{tabular}

* This species belong to the family Aphroditidae, this is the only report of a non-polynoid host parasitised by species of the genus Herpyllobius.

in most papers under the imprecise words "parasitic Copepoda". Bowman and Abele (1982) and Huys and Boxshall (1991) included the family among the Siphonostomatoida. However, this placement can no longer be accepted according to the new data derived from the study of the ontogeny of copepodid antennules and their phylogenetic implications (see Boxshall and Huys, 1998). The dissimilarities in the segmentation and armature pattern of the distal XXI to XXVIII antennular segments of the male copepodids with respect to that in Siphonostomatoida demonstrate the unjustified placement of the Herpyllobiidae among the Siphonostomatoida, as has been pointed out by Huys et al. (in press). In the latter paper the authors discuss the ordinal position of the family Chitonophilidae Avdeev and Sirenko, 1991, a highly modified group of meso- and endoparasitic genera on Polyplacophora and Gastropoda (see Avdeev and Sirenko, 1991, 1994; Huys et al., in press). The Chitonophilidae is placed among the Cyclopoida based on segmentation, aesthetasc pattern and armature of the compound segment XXIXXIII of the male copepodid antennule (Huys et al., in press).

In the known male copepodids of Herpyllobiidae (based on Herpyllobius and Eurysilenium species, see Lützen, 1968) the penultimate segment XXV is expressed as a distinct segment. This fact alone excludes the family from the Siphonostomatoida, in which this segment remains undivided from segment XXIV or is part of a large compound segment (see Boxshall and Huys, 1998: fig. 8; Huys et al., in press: fig. 14). The final placement of the Herpyllobiidae, however remains obscure at least with the research techniques currently available.

The male copepodid of Herpyllobius (see Lützen, 1968: 183 and fig. 3b) displays a poecilostomatoid pattern (see Boxshall and Huys, 1998: fig. 9) with one aesthetasc on each of the three terminal segments. The distal segment is considered to be the result of the fusion of the ancestral segments XXVI-XXVIII. The free segment XXV has one posterior seta and one aesthetasc, and segment XXIV (identified by the posterior seta) is fused to the proximal segments (armed with 3 anterior and 1 posterior setae, plus one aesthetasc).

Despite the close similarity between the male copepodid of Herpyllobius and Eurysilenium claimed by Lützen (1968) (in the general segmentation of the body, and structure and armature of the swimming legs) the structure of the antennules are noticeably different (see Lützen, 1968: 182-184, fig. 3). Moreover, the male copepodid of Eurysilenium retains part of the mouthparts [residual mandibles and maxillule (or maxilla)] that are completely absent in Herpyllobius. 
The male copepodid of Eurysilenium expresses a distinct segment XXIV, which is present in the cyclopoids (see Dudley, 1966 for Notodelphyidae, Huys et al., in press for Chitonophilidae), although it has also been observed in the family considered to be the most primitive within the poecilostomatoid lineage, the Erebonasteridae, (see Huys and Boxshall, 1990, Martínez Arbizu, 1996-97). The highly transformed body of the adult form of Eurysilenium, however, is at odds with a basal placement near the origin of the Poecilostomatoida.

Stock (1986) described Eurysilenium intermedium associated with the gallicole polynoid Harmothoe corralophila Day, 1960. The specific name refers to the intermediate position of this species between the genera Herpyllobius and Eurysilenium. However, some characters of this species should be checked. The anterior position of the stalk is not a diagnostic character placement in Eurysilenium because it is also present in Herpyllobius elongata (see Lützen, 1967: fig. 1). The presence of 4 segments in the antennule of male copepodid differs from that of Herpyllobius (3-segmented) and Eurysilenium (5-segmented); perhaps the author overlooked the presence of the short third segment illustrated by Lützen (1968: fig. $3 \mathrm{~g}$ ) for E. oblongum Hansen, 1887, although the author specifically discussed this feature. In addition, the antennule armature pattern of $E$. intermedium essentially corresponds with that of the Eurysilenium, differing only in the presence of an additional aesthetasc on the last segment, and the presence of a seta on the first one, which are absent in E. oblongum.

We therefore conclude that additional data from larval development and molecular taxonomy are necessary before further progress on this subject can be made. These new (additional) characters will most surely be useful in elucidating the relationships between genera within the Herpyllobiidae and in elaborating a plausible phylogenetic tree displaying the relative placement of this family with respect to the typical poecilostomatoids and cyclopoids. It is also true that the differences between Cyclopoida and Poecilostomatoida have been reduced with the description of the family Fratiidae by Ho et al. (1998), which display a mixture of morphological features from both orders. This fact makes it difficult to trace a clear boundary between the two orders, reflecting the possible existence of a continuum and supporting the paraphyly of the Cyclopoida, as has been pointed out by Huys et al. (in press).

\section{ACKNOWLEDGEMENTS}

The authors sincerely thank Rony Huys (The Natural History Museum, London) for sharing his knowledge about the importance of antennular ontogenetic features in the phylogeny of copepods. We wish to thank Brigitte Hilbig (Zoologisches Institut und Zoologisches Museum, Hamburg) for identifying the species of polynoids. The authors acknowledge the valuable assistance of the officers and crew of the R/V Polarstern, and the many colleagues on board during the EASIZ III cruise. Special thanks are addressed to Stefano Piraino (Intituto Sperimentale Talassografico C.N.R., Taranto) and Americo Montiel (Alfred-Wegener-Institut, Bremerhaven), who kindly provided most of the material studied and the preliminary identification of the polynoid hosts. Support for this work was provided by the CICYT projects ANT98-1739-E, and ANT99-1608E. We also thank Adrian Harrison (The Royal Veterinary and Agricultural University, Denmark) for linguistic advice. Geoff A. Boxshall and an anonymous referee are also thanked for their suggestions and criticisms. Mr. Tony Krupa is thanked for reviewing the final English version.

\section{REFERENCES}

Avdeev, G.V. and B.I. Sirenko. - 1991. Chitonophilidae fam. N., a new family of parasitic copepods from the chitons of the NorthWestern Pacific. Parazitologiva, 25: 370-374.

Avdeev, G.V. and B.I. Sirenko. - 1994. New species of copepod endoparasites of chitons. Parazitologiya, 28: 110-118.

Bowman, T.E. and L.G. Abele. - 1982. Classification of the recent Crustacea. In: L. G. Abele (ed.), The Biology of Crustacea. Vol. 1. Systematics, the fossil record, and Biogeography, pp 1-27. Academic Press, New York, etc.

Boxshall, G.A. and R. Huys. - 1998. The ontogeny and phylogeny of copepod antennules. Phil. Trans. R. Soc. Lond., B 353: 765-786.

Dudley, P.L. - 1966. Development and systematics of some Pacific marine symbiotic copepods. A study of the biology of the Notodelphyidae, associates of ascidians. University of Washington Press, Seattle, WA.

Gravier, C. - 1912. Sur l'habitat d'un Crustacé parasite annélidicole (Herpyllobius arcticus Steenstrup et Lütken). Bull. Mus. Hist. nat. Paris, 18: 30-33.

Gravier, C. - 1913. Crustacés parasites. 2 expéd. Antarct. Fr. Sci. Nat. 1913(1): 27-77.

Ho, J.-S., M. Conradi and P.J. López-González. - 1998. A new family of cyclopoid copepods (Fratiidae) symbiotic in the ascidian (Clavelina dellavallei) from Cádiz, Spain. J. Zool., Lond., 246: 39-48.

Huys, R. and G.A. Boxshall. - 1990. Discovery of Centobnaster humesi, new genus, new species (Erebonasteridae), the most primitive poecilostomatoid copepod known, in New Caledonian deep waters. J. Crust. Biol., 10: 504-519.

Huys, R. and G.A. Boxshall. - 1991. Copepod evolution, The Ray Society. London.

Huys, R., P.J. López-González, E. Roldán and A. Luque. - (in press). Brooding in cocculiniform limpets (Gastropoda) and familial distinctiveness of the Nucellicolidae (Copepoda): misconceptions reviewed from a chitonophilid perspective. Zool. J. Linn. Soc. 
Jensen, S. - 1900. Nogle oplysninger om Rhizorhina ampeliscae H.J.H., Herpyllobius arcticus Stp.-Ltk. og Fam. Herpyllobiidae H.J.H. K. Danske vidensk. Selsk. Forh., 1900(1): 61-112.

Laubier, L. - 1961. Contribution à la faunistique du coralligene, V. Herpyllobius arcticus Steenstrup et Lütken, copépode parasite d'annélide polychètes en Méditerranée occidentale. Vie Milieu, 12: 261-268.

López-González, P.J., J. Bresciani and M. Conradi. - 2000. Two new species of Herpyllobius Steenstrup and Lütken, 1861 and a new record of Herpyllobius antarcticus Vanhöffen, 1913 (parasitic Copepoda) from the Weddell sea, Antarctica. Pol. Biol., 23: $265-271$

Lützen, J. - 1964. A revision of the family Herpyllobiidae, (Parasitic Copepods) with notes on host and distribution. Ophelia, 1: 241-274.

Lützen, J. - 1966. The anatomy of the family Herpyllobiidae (Parasitic Copepods). Ophelia, 3: 45-64.

Lützen, J. - 1967. Herpyllobius elongata n. sp. and other Herpyllobiids (parasitic copepods) from the coastal waters of Southern
British Columbia and Northern Washington. Can. J. Zool., 45: 491-496.

Lützen, J. - 1968. On the biology of the family Herpyllobiidae (Parasitic Copepods). Ophelia, 5: 175-187.

Lützen, J. and B. Jones. - 1976. Two new species of Herpyllobius (Parasitic Copepoda) from New Zealand and the Antarctic. New Zeal. J. Mar. Fresh. Res., 10(2): 371-374.

Martínez Arbizu, P. - 1996/97. The monophyly of Erebonasteridae, with the description of Centobnaster severnicus sp. n. (Copepoda: Poecilostomatoida) from the Laptev Sea (Artic Ocean). Zool. Anz., 235: 263-270.

Stock, J.H. - 1986. Cases of hyperassociation in the Copepoda (Herpyllobiidae and Nereicolidae). Syst. Parasit., 8: 71-81.

Vanhöffen, E. - 1913. Herpyllobius antarcticus n. sp., ein an Enipo rhombigera Ehlers schmarotzender Copepode. Dtsch. Südpol.Exped., 13(5): 599-602.

Scient. ed.: M. Alcaraz 